\title{
Exploration on the Reform Path of Ideological and Political Education for Professional Degree Postgraduates-Taking Agricultural Engineering and Information Technology Field as an Example
}

\author{
Youwen Tian ${ }^{1}$, Tongyu $\mathrm{Xu}^{1, *}$, Jun Wang ${ }^{1}$ and Chunling $\mathrm{Chen}^{1}$ \\ ${ }^{1}$ School of Information and Electrical Engineering, Shenyang Agricultural University, Shenyang, Liaoning 110866, \\ China \\ *Corresponding author. Email: xutongyu@syau.edu.cn
}

\begin{abstract}
To adhere to the socialist university running direction, implement the fundamental task of moral education and foster talents, and meet the needs of cultivating new talents who know and love agriculture, taking agricultural engineering and information technology field as an example, this paper proposed the ideological and political teaching reform path of professional degree postgraduate courses in. Combined with the existing problems of ideological and political education of professional degree postgraduates, this paper put forward that the cultivation of prfessional degree postgraduates should establish the concept of moral education and foster talents, deeply excavate the elements of ideological and political education, actively explore new ideas and ways of ideological and political education, formulate scientific evaluation mechanism, which strengthen educational consciousness and improve educational ability. We confirmed that the proposed reform path could be enhance postgraduate not only to have solid basic theoretical knowledge and professional practical skills, but also to have the qualities of ideals and beliefs, feelings of family and country, knowing and loving agriculture, struggle spirit and so on, so as to cultivate practical and innovative high-quality application talents who meet the national agricultural needs.
\end{abstract}

Keywords: Professional degree postgraduate; ideological and political education; moral education and

foster talents; ideological and political resources

\section{INTRODUCTION}

General secretary Xi Jinping emphasized several times at the meeting that we should integrate ideological and political work throughout the whole process of education and teaching, and achieve full range of education and allround education and postgraduate education should cultivate a large number of high-level talents with both ability and integrity[1]. The Ministry of education has also repeatedly made it clear that ideological and political education construction is an important task to comprehensively improve the quality of talent training in the new era, requiring colleges and universities to promote curriculum ideological and political education construction, scientifically design curriculum ideological and political teaching system, and truly integrate curriculum ideological and political into the whole process of classroom teaching and talent training[2]. The Ministry of education also proposed to further improve the ideological and political education system, strengthen the ideological and political education of postgraduate courses, and build a number of curriculum ideological and political demonstration courses.
Postgraduate education shoulders the important mission of high-level talent training and innovation, and is an important cornerstone of national development and social progress. Professional degree postgraduate education is an important part of postgraduate education and an important channel to cultivate high-level applied talents[3]. Since the implementation of the professional degree postgraduate education system, a large number of practical talents have been trained for all walks of life in China. However, with the rapid development of higher education in China, the cultivation of professional degree postgraduates is also facing more and higher requirements. It is required that the cultivation of postgraduates with professional degrees in colleges and universities should take building morality and cultivating people as the fundamental task, take education as the goal, and cultivate qualified socialist builders and successors with ideals and beliefs, patriotism, ideological and moral cultivation, knowledge and insight and struggle spirit. This requires colleges and universities to further promote education and teaching reform and encourage teachers not only to impart knowledge to students, but also to complete value guidance.

The field of agricultural engineering and information technology of the master's degree in agriculture is mainly 
for the relevant agricultural management departments, enterprises and institutions and new agricultural business entities in this field to cultivate good ideological and moral character, strive to practice the socialist core values, love the motherland, abide by discipline and law, strong professional ability and professional quality, and be able to creatively engage in technical research, application, development practical and innovative high-level application-oriented professionals who carry out practical work such as promotion and management and actively serve China's agricultural and rural modernization and rural revitalization. Therefore, in the new era, how to strengthen the curriculum ideological and political education guidance of postgraduate professional courses in the field of agricultural engineering and information technology, guide students' thoughts with socialist core values, shape postgraduate students' character, make them continuously improve their ideological and political theoretical literacy, enhance cultural self-confidence, and always remember "strengthening agriculture and prospering agriculture" while learning basic professional theoretical knowledge, deepen the reform of postgraduate education and teaching in the field of agricultural engineering and information technology has become an urgent problem for postgraduate education managers.

Taking the master of agriculture in the field of agricultural engineering and information technology as an example, this paper analyzes the necessity and existing problems of curriculum ideological and political education, combined with the training characteristics of applied agricultural engineering and information technology talents, deeply excavates ideological and political education resources, explores new ways and methods of ideological and political education, and explores the effective evaluation mechanism of ideological and political education to improve the quality of curriculum teaching and the level of ideological and political education.

\section{NECESSITY OF IDEOLOGICAL AND POLITICAL EDUCATION IN PROFESSIONAL DEGREE POSTGRADUATE COURSES}

\subsection{Foundation of Adhering to the Socialist School Running Direction}

Agricultural Colleges and universities shoulder the historical mission of strengthening and revitalizing agriculture and serving the national agricultural development strategy. It is required that they must be deeply rooted in China and firmly adhere to the socialist school running direction, which is the foundation and key to the development of agricultural colleges and universities in the new era. The development direction of agricultural colleges and universities in the new era should be consistent with the goal of building socialism with Chinese characteristics and the concept of serving the development of "agriculture, rural areas and farmers", and always adhere to serving the promotion of agricultural and rural modernization and the all-round revitalization of rural areas. The field of agricultural engineering and information technology, as an important part of the master of agriculture, its ideological and political education is particularly important. It is necessary to fully tap the value connotation contained in the teaching of courses, experiments, internships and practices, effectively activate the educational function contained in each teaching link, and realize the same frequency resonance between the teaching of professional knowledge and the guidance of ideological value so as to stimulate agricultural college students to devote themselves to the cause of "agriculture, rural areas and farmers" and cultivate practical and innovative high-quality application talents in line with the national agricultural needs

\subsection{Important Measure to Realize the Fundamental Task of Moral Education and Foster Talents}

Moral education and foster talents is the foundation of Socialist Colleges and universities with Chinese characteristics. The so-called moral education and foster talents is to "guide the ideological value through the whole process of education and teaching, and realize the whole process and all-round education" [4]. Therefore, in the field of agricultural engineering and information technology in the new era, we should give full play to the value leading role of ideological and political education in all teaching links, so as to build a personality bureau of ideological and political education of the whole curriculum. The school running characteristics in the field of agricultural engineering and information technology in the new era determine that its teaching links have distinctive agricultural characteristics, which requires its ideological and political construction to be based on agricultural development, obey and serve the goal of agricultural talent training, and give full play to the functions of each teaching link in shaping the value of "agriculture, rural areas and farmers" and cultivating feelings for agricultural college students, truly implement the fundamental task of moral education and foster talents in agricultural colleges and universities in the new era.

\subsection{Need of Cultivating New Talents Who Know and Love Agriculture}

Agricultural Colleges and universities should take moral education and foster talents as the foundation, strengthen agriculture and prosper agriculture as their own responsibility, and cultivate more new talents who know and love agriculture. In the new era, agricultural colleges and universities should focus on the practical needs of cultivating new talents who know and love agriculture, solidly promote the ideological and political education 
construction in various teaching links, organically integrate ideological and political elements into the teaching process, and deepen the agricultural college students' understanding of China's 5000 year history of agricultural civilization and their feelings of "three agriculture", so as to guide the postgraduate students of agricultural colleges and universities to actively participate in the cause of "agriculture, rural areas and farmers", fight poverty and serve rural revitalization, and strive to cultivate a number of new talents who know and love agriculture with deep theory, wide vision and strong ability.

\section{PROBLEMS IN THE CURRENT IDEOLOGICAL AND POLITICAL EDUCATION CONSTRUCTION OF POSTGRADUATE COURSES}

\subsection{Understanding of Ideological and Political Education in Postgraduate Courses is Relatively Shallow}

Postgraduate students often pay attention to the improvement of scientific and technological level, but ignore the ideological and political education. Even if some postgraduate courses incorporate ideological and political content into the curriculum, they often ignore the differences and connections between postgraduate majors and ideological and political education, talk about ideological and political teaching without postgraduate majors, or simply separate majors from ideological and political courses, and mechanically and rigidly flood students with ideological and political knowledge, which resulting in the lack of understanding of the ideological and political education.

\subsection{Form of Ideological and Political Education for Postgraduates is Single}

At present, in most courses, the curriculum of ideological and political education only relies on the single way of classroom teaching, and does not run the ideological and political elements through the whole process of the rich and diversified curriculum teaching system. It also does not consider how to effectively match the form of curriculum with the educational goal of ideological and political education, how to take various forms in the process of postgraduate training, and how to closely combine with postgraduate research-based learning, as well as with the establishment of political consciousness and values. In addition, it did not consider how to run the course of ideological and political education through the whole process of the cultivation of postgraduate students' political literacy, theoretical literacy and moral literacy, strengthen the development in various links of education such as classroom teaching, experimental operation, and reflect the example power and spiritual pursuit of ideological guidance.

\subsection{Tutor's Ideological and Political Education Consciousness is not Strong}

For a long time, due to the deep-rooted concept of "morality" in ideological and political education and "talent" in professional education, some tutors have cognitive deviation on the function of professional courses, only impart theoretical knowledge in teaching, and ignore the important responsibility of educating people. At present, many postgraduate tutors still have a one-sided understanding of their own educational responsibility, pay more attention to the academic training of students, and ignore the training of politics, values and morality. In addition, due to undertaking a large number of scientific research tasks or social duties, some tutors neglect to seriously train their postgraduate students, lack of communication and communication outside classroom teaching, and have no time or intention to take into account students' Ideological and political education.

\subsection{Assessment Mechanism of Ideological and Political Education of Postgraduate Courses is not Perfect}

In the assessment and evaluation system of postgraduate in some colleges and universities, they often follow the traditional evaluation method, only evaluate the learning achievements and knowledge mastery of postgraduate students, pay attention to the evaluation of knowledge and scientific research ability, ignore the evaluation of Ideological and moral quality, and fail to establish an effective evaluation system for ideological and political education. On the other hand, it may be that the process of ideological and political content and the corresponding content can not be reasonably indexed, and the teaching effect of ideological and political education can not be evaluated, resulting in the difficulty of establishing the corresponding evaluation system, and the incentive mechanism of the evaluation system can not be implemented.

\section{REALIZATION PATH OF IDEOLOGICAL AND POLITICAL EDUCATION CONSTRUCTION OF POSTGRADUATE}

\subsection{To do Establish the Ideological and Political Concept and Clarify the Curriculum Objectives}

The guiding outline of ideological and political education construction in Colleges and universities clearly points out 
that ideological and political education construction focuses on the core point of comprehensively improving talent training ability, takes professional courses as the basic carrier, combines different curriculum characteristics, thinking methods and value ideas, deeply excavates curriculum ideological and political elements, and organically integrates them into all aspects and links of curriculum teaching [5]. In the new era, the fundamental task of postgraduate education is moral education and foster talents, clarify the objectives, requirements and content focus of ideological and political education of postgraduate courses in the field of agricultural engineering and information technology, closely focus on the development needs of national and regional agricultural informatization, establish a scientific curriculum outline, and explore the integration of ideological and political education into all links of teaching. We should deeply excavate the ideological and political education resources contained in various teaching links and teaching methods, and build a curriculum ideological and political system with comprehensive coverage, rich types, progressive levels and mutual support. The teaching content should adhere to the problem orientation, deepen the ideological and political education and teaching reform with an open vision, pay attention to cultivating students' feelings of family and country, and enhance students' sense of national pride and power consciousness.

\subsection{To do Excavates Ideological and Political Education Cases and Build Ideological and Political Database}

According to the training objectives of postgraduate students majoring in agricultural engineering and information technology and the concept of ideological and political education, we should deeply tap the ideological and political education resources. Firstly, combined with the struggle process of scientists in the field of agricultural informatization, carry forward their professionalism of facing difficulties, persistent innovation and climbing the peak, and encourage postgraduates to be first, positive and serve the country with science and technology. For example, Academician Wang Maohua of China Agricultural University has always adhered to the sense of responsibility and mission for a long time, persevered and indomitable, and improved the spirit of inquiry, "craftsman spirit" and key research spirit for postgraduates on the road of chasing their dreams. Secondly, combining online video, national agricultural policy, social research, and making video materials, we can collect ideological resources of curriculum, so that postgraduates can understand $\mathrm{Xi}$ Jinping's thought of agriculture, rural areas and farmers, and the layout of agricultural modernization. We should master the main problems faced by China's agriculture and forestry development and the challenges of tackling poverty. So as to enhance the postgraduates' sense of mission and responsibility to participate in the modernization of agriculture and forestry, and constantly strengthen the postgraduates' education of "agriculture, rural areas and farmers". Finally, combined with the postgraduates own learning and scientific research experience. There are many excellent postgraduates in our university. They have high political quality and ideological and moral cultivation, study hard, are good at thinking, and have made excellent achievements in scientific research and competition. The advanced deeds of these postgraduate students will also stimulate the improvement of the moral standards of the surrounding postgraduate students. In short, the collection and dissemination of ideological and political education resources can continuously improve the moral quality and cultural literacy of postgraduates, and guide postgraduates to consciously shoulder the important task of national rejuvenation.

\subsection{Combined with the Curriculum Ideological and Political Objectives, Studies the Ideological and Political Education Evaluation Methods}

In combination with the "three-in-one" ideological and political education objectives of knowledge transfer, ability training and value shaping, a dynamic three-dimensional evaluation system should be established for postgraduate professional curriculum ideological and political education. "Five Simultaneities" assessment scheme shouid be formulated, that is, while graduates carry out training links such as curriculum learning, topic opening report, midterm assessment, scientific research practice and graduation defense, in the course assessment The opening report, mid-term assessment, scientific research practice, graduation defense and other assessment links should also be integrated into the assessment contents of ideological and political education in the course. This mainly strengthen the cultivation of students' independent ideological and political education learning ability, guide them to take strengthening agriculture and prospering agriculture as their own responsibility, establish the consciousness and belief of writing papers on the land of the motherland, and enhance students' ability to serve agricultural and rural modernization The sense of mission and responsibility of serving the overall revitalization of the countryside, including the students' ideals and beliefs, moral quality, scientific spirit and love for agriculture, focuses on the students' problem-solving ability, innovation ability, national self-confidence and agricultural consciousness, and evaluates the postgraduates' moral quality and academic level in all links of the whole process of cultivating postgraduates.

\subsection{To do Enhance the Tutor's Ideological and Political Education Awareness and Ability}

Postgraduate tutors with professional degrees are the first responsible person for graduate training and important executors of ideological and political education teaching and reform of postgraduate courses. They are not only the 
guide of students' majors, but also the guide of personality shaping. In 2020, the Ministry of Education issued the code of conduct for postgraduate tutors, which requires tutors to "adhere to correct ideological guidance" and "be both academic tutors and life tutors". Therefore, while imparting theoretical knowledge and professional skills, postgraduate tutors should give full play to the educational function of professional courses, and cultivate the majority of postgraduate students into new talents who not only have exquisite agricultural and forestry knowledge, but also have deep feelings of "agriculture, rural areas and farmers". On the other hand, postgraduate tutors should stimulate their own initiative in educating people and strengthen their mission of teaching and educating people. In the process of training postgraduate students, we should have a keen insight into and carefully refine the ideological and political elements contained in professional courses, such as political identity, family and country feelings, cultural self-confidence, moral cultivation and awareness of the rule of law. At the same time, postgraduate tutors should also deeply study students' emotions, attitudes and values, embody the concept of education in all links and aspects of postgraduate teaching, so as to realize the organic unity of teaching and education in the deep integration of knowledge transfer and value guidance.

\section{CONCLUSION}

Taking agricultural engineering and information technology field as an example, it expounds that ideological and political education as an important content of postgraduate education reform for professional degrees is considered as the practical needs of strengthening and improving the ideological and political work in agricultural colleges and universities under the background of the new era in this paper. Combined with the problems existing in the current ideological and political education, such as shallow understanding, single form, weak mentor consciousness and imperfect assessment mechanism, the cultivation of professional degree postgraduates should be established the concept of curriculum ideological and political education and clarify the curriculum objectives. We should deeply excavate the elements of curriculum ideological and political education, actively explore new ideas and ways of curriculum ideological and political education, formulate a scientific evaluation mechanism, strengthen the awareness of educating people. We confirmed that the proposed reform path could be enhance postgraduate professional practical skills, have the qualities of ideals and beliefs, feelings of family and country, knowing and loving agriculture, struggle spirit and so on, and meet the national agricultural needs.

\section{ACKNOWLEDGMENT}

Key research topics of the working committee of agriculture and forestry of China Association of degree and postgraduate education"Research and practice of ideological and political education model for postgraduate courses in agricultural and forestry colleges from the perspective of " three complete education "(2021-NLZXZD10)" and Shenyang Agricultural University Postgraduate education and teaching reform research project "Research, construction and application of online and offline hybrid course of spectral imaging technology and its application(2020-yjs-47)"

\section{REFERENCES}

[1] Xi Jinping.Adapt to the needs of the party and the state's career development, cultivate a large number of high-level talents with both ability and integrity. People's daily, 2020.07.30

[2] OU Shifeng, JIANG Peihe, GAO Ying. Exploration and Teaching Evaluation of Ideological and Political Education Elements of Professional Degree Courses for Information Postgraduates, Science and education guide, pp. 50-52, March 2021.DOI: 10.16400/j.cnki.kjdkx. 2021.03 .018

[3] He Suibo and Liu Junqi, Service demand, innovative mode, highlighting characteristics and improving quality - a summary of the two-year comprehensive reform of professional degree postgraduate education, Degree and postgraduate education, pp. 1-6, January 2018. DOI: 10.16750/j.adge.2018.01.001

[4] The CPC Central Committee and the State Council. Opinions on strengthening and improving ideological and political work in Colleges and Universities under the new situation. 2017.2.27.http://www.gov.cn/ xinwen/2017 - 02/27/content_5182502. html.

[5] Ministry of education. Notice on printing and distributing the guiding outline for ideological and political construction of courses in Colleges and Universities. 2020.6.1. http://www.moe.gov.cn/srcsite /A08/ s7056/202006/t20200603_462437.html. 